\title{
ISU LINGKUNGAN \\ DALAM PERSPEKTIF KALAM, FIQH, DAN TASAWUF
}

\author{
Sukarni
}

IAIN Antasari, Jl. Letjen Suprapto No. 19 Pontianak, sukarni_muin@yahoo.com

\begin{abstract}
There is no doubt that the problem of environment has become the most formidable issue faced by human being in the modern history. The danger imposed by the environmental crisis is much greater than the danger of any forms of war. This crisis has thus become the greatest enemy of humanity. The level and extent of the danger requires equally a great effort to address and tackle it. It is here that this paper tries to contribute. It attempts to offer an Islamic perspective of environment and its conservation. The paper is convinced that Islam is rich with perspectives on this issue. It therefore, introduces the many theories and views on environment that the sciences of Islam have spoken about. It brings into discussion the view of the science of theology (kalam), jurisprudence (figh) and sufism (tasawuf) on environment. Each of these sciences is discussed in relation to the others, as well as in the context of what the paper calls figh lingkungan (the jurisprudence of environment). The idea that underlines the paper is that these sciences are-generally speaking-concerned with the idea of personal and collective responsibility; an idea that already has a direct relevance to the problem of environment.
\end{abstract}

Keywords: Environmental crisis, responsibility, jurisprudence.

\section{Pendahuluan}

Senyatanya terdapat sinergitas antara kalam, fiqh, dan tasawuf dalam memahami dan memperlakukan alam semesta yang kemudian membentuk fiqh lingkungan. Sinergi ini dimaksudkan agar fiqh lingkungan memiliki daya kekuatan yang bersumber dari kesadaran akan ketuhanan (ekotaubid) dan kesadaran etika (ekosofi). Fiqh sebagai produk pemikiran lahir dari berpikir kreatif berdasar pemahaman terhadap ajaran Islam dengan sejumlah asumsi, paradigma, bahkan 
dari nilai-nilai dan pandangan hidup yang diyakini. Sistem nilai ini terbentuk dari pergumulan panjang antara manusia dengan lingkungan hidupnya dalam berbagai kepentingan. Sistem nilai itu berperan dalam menentukan bentuk tindakan seseorang atau masyarakat. Sistem nilai yang menjelma dalam bentuk peta kognitif dijadikan manusia atau masyarakat untuk memahami dan menginterpretasikan pengalaman dan lingkungannya serta menjadi kerangka landasan untuk mewujudkan kelakuan mereka. Oleh karena merumuskan fiqh lingkungan bukan semata-mata proses merumuskan kepastian hukum yang bersifat etik, tetapi terkait dengan masalah sosial yang bersifat emik. Oleh karena itu, penelaahan terhadap sistem nilai yang menjadi pandangan dunia menjadi sangat penting. Pandangan dunia adalah hal yang mengacu pada sejumlah gagasan dan keyakinan yang dengan gagasan dan keyakinan itu seseorang akan bertindak.

Sistem nilai yang mempengaruhi sifat dan sikap manusia atau masyarakat terhadap lingkungan hidupnya dapat diidentifikasi dari sikapnya terhadap alam yang cenderung berubah-ubah, tergantung motif dan kepentingan yang sedang menyertainya. Dalam pandangan syariah, semesta alam adalah ciptaan Tuhan yang diamanahkan kepada manusia agar ia mengelolanya dengan penuh tanggung jawab. Tugas utama manusia sebagai pemegang kebijakan (khalifab) adalah memakmurkan bumi yang berarti menjaga lingkungannya agar tetap dapat mendukung kehidupan secara keseluruhan. Dengan demikian, dalam ajaran Islam, sebenarnya terdapat pandangan dunia yang khas sebagai idealisme dalam memandang alam semesta secara umum dan lingkungan hidup secara khusus.

Krisis lingkungan hidup yang dirasakan akhir-akhir ini hanya dapat diatasi dengan melakukan perubahan cara pandang dan perilaku manusia terhadap alam secara fundamental dan radikal. Diperlukan pola hidup atau gaya hidup baru yang tidak hanya menyangkut orang perorang, tetapi juga budaya masyarakat secara keseluruhan. Dibutuhkan etika lingkungan hidup yang menuntun manusia untuk berinteraksi secara baru dalam alam semesta. Dengan kata lain, krisis lingkungan hidup global yang terjadi dewasa ini sebenarnya bersumber pada kesalahan fundamental filosofis dalam pemahaman atau cara pandang manusia mengenai dirinya, alam, dan tempat manusia dalam keseluruhan ekosistem. Kesalahan pandangan ini melahirkan perilaku yang keliru dalam memandang alam dan keliru pula dalam menempatkan dirinya di dalam ekosistem alam. Oleh 
karena itu pembenahan krisis lingkungan harus dimulai dari pembenahan pandangan hidup ini.

Kesalahan cara pandang itu bermula dari paham antroposentrisme yang memandang manusia sebagai pusat alam semesta dan hanya manusia yang mempunyai nilai, sementara alam dengan segala isinya dianggap sebagai alat (instrumen) bagi pemuasan kepentingan dan pemenuhan kebutuhan hidup manusia. Menurut paham ini, manusia dianggap berada di luar, di atas, dan terpisah dari alam. Bahkan, manusia dianggap sebagai penguasa terhadap alam yang boleh melakukan apa saja terhadap alam. Cara pandang seperti ini akan melahirkan sikap dan perilaku eksploitatif tanpa peduli sama sekali terhadap alam dan isinya yang dianggap tidak mempunyai nilai pada dirinya sendiri.

Antroposentrisme adalah sebuah paham yang menegaskan bahwa manusia menjadi pusat alam. Orientasi kepada alam tidak diletakkan sebagai tujuan tindakan sosial, melainkan ia hanya dinilai sebatas alat bagi kepentingan manusia. Kekayaan alam yang tersebar di berbagai penjuru tidak lebih dipandang kecuali sebagai alat untuk memenuhi kepentingan manusia. Manusia dipersepsi sebagai pendobrak (frontier) dan penakluk alam.

Kalau dilacak ke belakang, paham ini bermula dari sebuah pemikiran filsafat Yunani yang dicetuskan oleh Aristoteles dalam bukunya, Politics. Ia menyatakan bahwa tumbuban disiapkan untuk. kepentingan binatang, dan binatang disiapkan untuk kepentingan manusia. Rene Descartes juga menyatakan bahwa manusia berkedudukan lebih terhormat dibanding makbluk lain. Dari sini dapat dilihat bahwa etika antroposentrisme bersifat sangat instrumentalis, sebab pola hubungan manusia dan alam dilihat hanya dalam dimensi instrumentalnya saja. ${ }^{1}$

Manusia pendobrak alam memiliki tiga persepsi. Pertama memandang alam sebagai pemberi sumber kehidupan yang tidak terbatas dengan keyakinan bahwa alam akan selalu ada dan melayani. Kedua memandang manusia sebagai makhluk hidup yang dikonsepsi di luar alam, bukan bagian dari alam. Manusia eksklusif dan memiliki dunianya sendiri, tidak merasa bersama dengan alam. Ketiga memandang alam sebagai sesuatu yang perlu dikuasai. Hanya alam yang memberikan keuntungan kepada manusia yang akan dilestarikan, sedangkan yang tidak menguntungkan akan ditelantarkan.

${ }^{1}$ Sony Keraf, Etika Lingkungan (Jakarta: Kompas, 2002), 34. 
Dalam konteks konservasi lingkungan, ada beberapa kelemahan paham ini. Pertama, mengabaikan lingkungan yang dirasakan tidak memberikan keuntungan kepada manusia, kedua, eksploitasi yang dilakukan berubah-ubah sesuai kepentingan manusia, dan ketiga, yang dipentingkan hanya nilai-nilai ekonomis jangka pendek. ${ }^{2}$

Paham antroposentrisme dilatarbelakangi oleh rasa percaya diri manusia yang berlebihan dalam mengelola alam yang dianggapnya tidak pernah habis. Teknologi dapat menyelesaikan segalanya, termasuk keyakinan bahwa teknologi dapat menyelesaikan dampakdampak negatif dari eksploitasi alam. Di samping itu, paham ini juga dilatarbelakangi oleh keyakinan bahwa nilai sukses diukur berdasarkan akumulasi materil.

Cara pandang dan sistem nilai tentang relasi manusia dan alam, dalam perkembangan ideologi hasil rumusan manusia, cenderung berubah. Antroposentrisme berkembang menjadi biosentrisme, ${ }^{3}$ ekofeminisme, ${ }^{4}$ hingga ekosentrisme. ${ }^{5}$ Dari berbagai paham tersebut muncul pula berbagai teori tentang relasi antara manusia dan alam, seperti teori determinisme lingkungan, ${ }^{6}$ dan ekologi budaya. ${ }^{7}$

\footnotetext{
${ }^{2}$ Ibid., 47.

3 Biosentrisme adalah sebuah paham bahwa bukan hanya manusia yang menjadi terhormat dalam alam raya ini, tetapi semua binatang memiliki hak untuk dilindungi. Oleh karena itu, biosentrisme sering disamakan dengan animalsentrisme. Paham biosentrisme memiliki dua pokok pandangan. Pertama, alam memiliki nilai dalam dirinya sendiri yang berarti bahwa setiap makhluk yang ada di alam ini memiliki nilai intrinsik tanpa harus mengaitkannya dengan manusia. Kedua, alam diperlakukan sebagai moral, terlepas dari apakah ia bermanfaat atau tidak bagi manusia. Kehidupan alam harus dihormati dan diperlakukan dengan penuh tata krama.

${ }^{4}$ Eko-feminisme adalah gerakan lingkungan yang tidak lepas dari perkembangan paham feminism. Lihat Rakhmad K. Dwi Susilo, Sosiologi Lingkungan (Jakarta: Rajawali, 2008), 131.

5 Jika dibandingkan dengan biosentrsieme, ekosentrisme ternyata memiliki pandangan yang lebih luas. Menurut paham ini, perjuangan penyelamatan terhadap lingkungan alam tidak hanya mengutamakan penghormatan terhadap spesies tertentu saja, tetapi penghormatan atas seluruh kehidupan.

${ }^{6}$ Dalam masyarakat bersahaja, hubungan antara manusia dan lingkungan ditandai dengan determinisme lingkungan terhadap kehidupan manusia. Dalam hal ini seluruh aspek budaya, perilaku, bahkan nasib manusia dipengaruhi, ditentukan, dan tunduk pada lingkungan.

7 Ekologi budaya sebagai sebuah teori yang mengatakan bahwa antara lingkungan dan budaya memiliki hubungan dialektis yang masing-masing saling mempengaruhi. Inti dari teori ini adalah bahwa lingkungan dan budaya tidak dapat dilihat terpisah, tetapi sebagai hasil campuran yang berproses lewat dialektika.
} 
Islam sebagai agama dengan misi menebarkan rahmat bagi semesta alam, memiliki ajaran cara pandang yang khas terhadap lingkungan hidup dan terhadap semesta alam pada umumnya yang dapat dikonsepsikan sebagai ekosharîah.

Secara bahasa, term ekoshari"ah terdiri dari "oikos" yang berarti rumah tangga dan sharîh yang berarti ajaran Islam. Secara istilahi, ekoshari'ah dapat didefiniskan sebagai nilai-nilai ajaran Islam yang berpihak terhadap lingkungan hidup. Istilah ini menegaskan bahwa ajaran agama (Islam) telah meletakkan pondasi nilai-nilai dasar dalam kerangka membangun kehidupan yang ramah lingkungan. Nilai-nilai dasar itu dapat digali dari sumber utama ajaran Islam, al-Qur'ân dan Hadîth. Dari sumber utama itu dapat diturunkan norma-norma dasar lapisan kedua berupa platform yang dirumuskan dalam ranah tauhid, tasawuf, dan usûl al-fiqh.

Norma dasar lapisan kedua ini tentu memerlukan upaya revitalisasi dan penyesuaian-penyesuaian untuk kemudian diproyeksikan menjadi mesin produk aturan-aturan yang lebih praktis sampai kepada implementasinya di lapangan. Dengan ekosharíah, akan lahir paling tidak dua paradigma. Pertama, bahwa konsep-konsep konservasi lingkungan adalah bagian dari ajaran Islam, karena konsepkonsep itu merupakan hasil deduksi dan induksi dari sumber ajaran Islam. Kedua, bahwa kerja konservasi lingkungan yang dilakukan oleh manusia adalah bagian dari keberagamaan, atau sebagai bagian dari implementasi iman seseorang. Dengan demikian, ekosharîah diharapkan menjadi pandangan dunia yang mewarnai paradigma masyarakat Muslim.

Dengan cara pandangnya yang khas, ekoshari'ah akan menjadi pintu masuk bagi usaha-usaha konservasi lingkungan berbasis nilai ajaran Islam yang bukan hanya untuk memperbaiki kualitas perlindungan lingkungan di negara-negara Muslim, tetapi dapat juga untuk menopang gerakan global dalam masalah pembangunan berkesinambungan. Dalam arti inilah, penggalian kembali pesan-pesan konservasi lingkungan dari perspektif syariah dapat menjadi tonggak sejarah bagi gerakan environmentalisme global. ${ }^{8}$

\section{Fiqh Lingkungan}

Secara generik, fiqh lingkungan dimaknai sebagai hasil ijtihad ulama tentang hukum yang mengatur perilaku mukallaf dalam

8 Mudhofir Abdullah, Al-Qur'an \& Konservasi Lingkungan (Jakarta: Dian Rakyat, 2010), 19. 
interaksinya dengan lingkungan. Aturan perilaku, dalam fiqh diwadahi dalam lima varian hukum: al-wujûb, al-mustạ̣ab, al-ibâhah, al-karâhah, dan al-hurmah. Dalam konteks kesadaran lingkungan, fiqh tampaknya tidak cukup dipahami semata-mata dalam konteks fiqh, tetapi memerlukan keterlibatan dua ilmu lain, kalam/tauhid dan tasawuf/etika sebagai pengawalnya. Tauhid memberikan penekanan pada kesadaran bertuhan yang telah menciptakan alam (lingkungan). Penghargaan terhadap semua ciptaan Tuhan adalah basis yang sangat penting dalam membangun keniscayaan kesadaran lingkungan. Kesadaran berlingkungan dalam perspektif tauhid dibahas dalam tema ekotauhid. Tasawuf/etika memiliki peran penting dalam membangun kesadaran yang sangat tinggi dalam melaksanakan ajaran Tuhan. Berbeda dari fiqh yang membangun kesadaran melalui kepastian hukum dengan ukuran-ukuran konkret, tasawuf menekankan kesadaran yang muncul dari dalam diri seseorang. Kesadaran lingkungan dalam perspektif tasawuf dibahas dalam tema ekosofi.

\section{Ekotauhid}

Ekotauhid diartikan sebagai serangkaian premis yang membahas interelasi antara agama dan alam dalam perspektif tauhid (ketuhanan). Dalam sejarah pemikiran, istilah ini muncul dari kritik Lynn White terhadap teologi Kristiani yang mengajarkan tentang penguasaan alam yang terlampau eksploitatif sehingga mengakibatkan kerusakan lingkungan. White juga memandang bahwa amanat Alkitab untuk mendominasi alam yang disertai orientasi Kristen dan bersifat antroposentrik menjadi penyebab munculnya pendekatan terhadap alam yang bersifat instrumental, bukan menghormati sehingga menjadi lahan subur bagi perkembangan sains dan teknologi yang bersifat destruktif terhadap lingkungan.'

Dalam ajaran Islam, tauhid (sebutan yang lebih khusus untuk teologi) adalah sentral dalam beragama. Konsep tauhid menciptakan cara pandang setiap Muslim yang menyatukan semua gerak manusia, lahir dan batin, untuk kebaikan dan kepasrahan kepada Tuhan. Dalam kaitan ini, ungkapan bahwa iman itu terbagi tiga dan saling bersinergi (diakui dengan lidah, diyakini dengan hati, dan diamalkan dalam perbuatan) menjadi landasan tauhid yang sebenarnya.

Sebagai pandangan hidup, tauhid memandang alam semesta berasal dari Allah, dalam genggaman Allah, dan akan kembali kepada-

${ }^{9}$ Ibid., 133-134. 
Nya, segala sesuatu berpusat kepada-Nya. Dengan demikian, mengonservasi alam sama dengan berbuat baik kepada Tuhan dan berbuat baik kepada dirinya sendiri, sebaliknya setiap tindakan destruktif terhadap alam sama dengan berbuat zalim kepada Tuhan dan kepada dirinya sendiri. Term kufr dengan berbagai kata turunannya ${ }^{10}$ yang tersebar dalam banyak ayat al-Qur'ân sama dengan tidak bertanggung jawab atau membiarkan karunia Allah, termasuk nikmat lingkungan hidup. Dari sinilah titik tilik tauhid memandang relasi antara manusia dan Tuhan.

Dimensi ekologi dalam teologi dalam perspektif yang lebih ekstrim dapat dilihat dalam pemikiran Ibn 'Arabî. Ibn 'Arabî mengatakan bahwa alam adalah tajalli (manifestasi) Tuhan. Sebagai manifestasinya, alam adalah penampakan Tuhan yang teraktualisir. Pengagungan terhadap alam bukanlah sebagai suatu sikap kufur atau syirik, tetapi pengejawantahan dari paham dan sikap tauhid. ${ }^{11}$ Terlepas dari keabsahan panteisme Ibn 'Arabî dalam teologi konvensional, faham ini dapat dijadikan sebagai pijakan etik untuk keharusan melindungi alam, karena posisinya sebagai manifestasi Tuhan. Pandangan panteisme bukan untuk menyajikan struktur keyakinan syirik, tetapi sebagai alat untuk menumbuhkan rasa hormat kepada alam sebagai bagian dari diri sendiri dan Tuhan. Dengan demikian, pandangan ini memiliki kontribusi positif bagi konservasi lingkungan.

Ekotauhid dapat pula ditilik dari perspektif "Allah sebagai alKhâliq". Karena semua yang ada adalah ciptaan dan manifestasi-Nya (dari kemahakuasaan dan kemahasempurnaan-Nya), maka Allah adalah pusat segalanya. Fazlur Rahman menyebutkan bahwa Allah memberikan makna dan kehidupan kepada segala sesuatu, Dia serba meliputi, Dia tidak terhingga, segala sesuatu selain Dia tampak keterbatasannya, dan ini menandai bahwa ia adalah ciptaan Tuhan. ${ }^{12}$

Pencipta kosmos (al-Khâliq) yang di dalam al-Qur'ân disebut Allah disebut lebih dari 2500 kali (jumlah ini belum termasuk kata-kata lain yang memiliki kaitan makna sebagai pencipta, seperti rabb). Kalau diperhatikan dengan seksama, nama-nama itu bersifat fungsional. Artinya, di samping sebagai pencipta, Allah juga pemberi petunjuk

10 al-Qur'ân, 14: 28-29, dan 33-34; al-Qur'ân, 16: 112-115.

11 Kautsar Azhari Nur, "Wahdatul Wujud Ibn Arabi dan Panteisme" (Disertasi-IAIN Syarif Hidayatullah, Jakarta, 1993), 31-36.

12 Fazlur Rahman, Tema-tema Pokok al-Qur'an, terj. Anas Mahyuddin (Bandung: Pustaka, 1993), 5-6. 
dan sekaligus sebagai pemelihara. Karena fungsional, maka Allah bersifat aktif, tidak tidur, dan tidak mati. ${ }^{13}$

Konsep khalífat Allâh fî al-ard juga dapat memperjelas relasi antara Tuhan, manusia, dan alam dalam konteks ketauhidan. Secara etimologis, kata khalifah diambil dari kata "khalafa-yakhlufu" yang bermakna "mengganti", "belakang", dan "pergantian atau suksesi". ${ }^{14}$ Ketika dikaitkan dengan kata "Allah", maka muncul arti wakil Allah. Dalam konsep al-Qur'ân, manusia sebagai khalîfah memiliki dua fungsi, wakil dan pemegang amanah. Konsep khalifah akan semakin jelas maknanya ketika dipergunakan dalam menyebut kepemimpinan pasca Rasul. Pada saat itu, khalifah memiliki makna pemegang otoritas politik. Hal ini sangat logis karena dalam rangka mengemban amanah, kekuatan politik sangat diperlukan. Dari sinilah dapat dipahami makna ûli al-amr yang terdapat dalam Q.S. al-Nisâ' [4]: 59 yang mewajibkan kepada setiap orang beriman untuk taat kepada Allah dan Rasul serta ulli al-amr yang berarti pemegang otoritas kekuasaan dalam rangka menjalankan amanah.

Konsep wakil dalam teologi Islam tidak sama dengan konsep Barat. Dalam politik demokratis yang dikembangkan di Barat, wakil adalah wakil rakyat, yang berkuasa adalah rakyat. Dalam Islam, wakil adalah wakil Tuhan di bumi yang bertugas memakmurkan alam. Oleh karena itu, dalam konteks ekologi, konsep khalîfat Allâh ini sangat penting karena akan memberikan makna bahwa manusia menempati posisi sentral dalam menjalankan amanah ${ }^{15}$ sekaligus memakmurkan $^{16}$ alam dan lingkungannya.

Dengan penalaran dan pemahaman yang membahas keyakinankeyakinan kepada Allah dan ajarannya, ekotauhid dapat menjadi instrrumen bagi konservasi lingkungan. Konsep tauhid yang menjadi inti ekotauhid dapat menjadi basis perilaku etis dan moral manusia dalam memperlakukan alam lingkungan dan dengan tujuan sematamata mencari riḍ̂a Allah swt. Melalui serangkaian kegiatan yang

${ }_{13}$ Abdullah, Al-Qur'an \& Konservasi, 155.

${ }^{14}$ Ibn Fâriz b. Zakariyâ, Mujjam Maqâyis al-Lughab (Mesir: Muștafâ al-Bâb al-Halabî, 1972), 210

15 Dalam Q.S. al-Ahzâb (33): 72 ditegaskan bahwa amanah adalah tugas-tugas keagamaan yang semula ditawarkan kepada bumi, langit, dan gunujng, Namun, mereka enggan dan kemudian Allah memilih manusia untuk memikulnya. Lihat alQur'ân, 33: 72.

${ }_{16}$ Dalam Q.S. Hûd [11]: 61, Allah menegaskan bahwa salah tugas manusia adalah memakmurkan bumi. Lihat al-Qur'ân, 11: 61. 
bersumber dari kebijakan dalam kepemimpinan religius dalam bentuk khalîfat Allâh fì al-ard.

Dalam kearifan teologis, ulama Banjar semisal Shaykh Arsyad alBanjari dengan Kanz al-Ma'rifah-nya dan Shaykh Nafis dengan al-Durr al-Nafìs-nya dikonsepsikan waḥdat al-wujûd. Dalam Kanz al-Ma'rifah, Shaykh Arsyad menjelaskan tentang konsep "mengenal diri". Menurutnya, mengenal diri adalah pintu masuk mengenal Tuhan. Mengenal diri melalui tiga jalan yang saling bersinergi: mengenal asal kejadian, mematikan diri sebelum mati, dan mushâhadah. Asal kejadian, menurutnya, adalah dari Nur Muhammad. Mati sebelum mati berarti meyakini bahwa lâ qâdira, lâ murîda, lâ 'âlima, lâ hayya, lâ samî'a, lâ bașîra, lâ mutakallima fî al-haqî̀qah illâ Allâh. Adapun mushâhadah diinsafi melalui mubâạarah dan baqâ' bi Allahb. ${ }^{17}$ Tentang tauhid, Shaykh Nafis menjelaskan konsep waḥdat al-af'âl wâ al-asmâ wa al-sifât, wa al-dhât. Waḅdat al-dhât, menurut Nafis adalah maqâm yang tertinggi dalam spiritualitas seseorang. ${ }^{18}$

Implementasi dari kearifan teologis dua ulama Banjar tersebut, dalam kaitan dengan kesalehan lingkungan, sangat tampak dalam konsep pengesaan Tuhan yang menurut Shaykh Arsyad berwujud dalam konsep "mengenal diri untuk mengenal Tuhan" dan konsep Shaykh Nafis, waḥdat al-dhât. Dua konsep ini dapat didorong untuk memberikan energi positif bagi tindakan-tindakan konservasi lingkungan. Menyayangi lingkungan sama dengan menyayangi Penciptanya, Allah táâlâ; merusak lingkungan sama dengan merusak Penciptanya.

\section{Ekosofi dalam Membangun Akhlaq Lingkungan}

Konservasi lingkungan dapat pula didekati melalui akar-akar kearifan yang bersumber dari tradisi filsafat dalam hubungannya dengan lingkungan yang dalam hal ini dimaksudkan sebagai kearifankearifan yang berakar dari tradisi tasawuf. Meski antara filsafat dan ekologi memiliki dasar-dasar pijakan yang berbeda, tetapi yang dicari adalah titik-titik temu dari keduanya yang dapat mendorong spirit

\footnotetext{
17 Muhammad Arsyad al-Banjari, Kan₹ al-Ma'rifah (manuskrip), 1-6. Manuskrip ini berasal dari Tim Peneliti IAIN Antasari yang melakukan survei terhadap karya Shaykh Muhammad Arsyad pada tahun 1999.

18 Muhammad Nafis al-Banjari, al-Durr al-Nafis (Singapora: Al-Haramain, t.th.), 1 dan 13.
} 
konservasi terhadap lingkungan berupa nilai-nilai moral, kearifan, cinta, dan kebajikan. ${ }^{19}$

Penghubungan antara perspektif tasawuf dan masalah konservasi lingkungan terjadi karena di dalam tasawuf terdapat aspek-aspek yang sangat konstruktif bagi konservasi lingkungan. Aspek-aspek itu antara lain: zubd (penolakan terhadap materi berlebihan), dhiker dan fiker (mengingat dan merenung kemahabesaran Allah), dan ḥubb (cinta).

Tasawuf secara keseluruhan adalah ajaran tentang akhlaq atau etika, baik etika terhadap Allah maupun terhadap manusia dan alam semesta. Kedalaman reflektif tradisi tasawuf akan mendorong seseorang untuk lebih arif terhadap semua hal, termasuk terhadap lingkungan. Dalam pandangan Ibn al-Qayyim, etika bahkan menjadi esensi agama. Ia mengatakan bahwa semua isi agama adalah etika dan barangsiapa bertambah etikanya, maka bertambah pula agamanya. Hal ini memperoleh legitimasi dari hadîth Nabi yang menegaskan bahwa Rasulullah diutus adalah untuk menyempurnakan akhlaq. ${ }^{20}$

a. Al-Zubd

Al-zubd secara harfiah berarti pantang, penolakan (material), dan sikap asketik. ${ }^{21}$ Dalam tasawuf, zubd adalah upaya keras untuk melepaskan diri dari kesenangan duniawi sekalipun dihalalkan untuk tujuan melepaskan segala sesuatu yang dapat menjauhkan diri dari Tuhan. ${ }^{22}$ Makna zuhd kemudian menjadi usaha meninggalkan hal-hal yang hanya kesenangan semata. ${ }^{23}$ Dengan makna terakhir ini, zâabid (pengamal zubd), tidak berarti meninggalkan kesenangan duniawi, tetapi hanya membatasi kepada hal-hal yang memang diperlukan.

Pemaknaan zubd seperti ini semakin memberikan jalan bagi hubungannya dengan konservasi lingkungan. Zuhd bukan hanya sikap mental yang menjadi pandangan hidup, tetapi berwujud dalam kehidupan yang sangat penting dalam rangka menekan laju angka konsumsi dan produksi dengan pertimbangan keberlanjutan.

Pertumbuhan jumlah penduduk, pola konsumsi yang berlebihan yang terkait langsung dengan produksi memberikan tekanan besar

${ }^{19}$ Abdullah, Al-Qur'ân \& Konservasi, 185-186.

20 Abû Bakr Aḥmad b. al-Ḥusayn b. 'Alî b. Mûsâ al-Bayhaqî, Al-Sunan al-Kubrâ, Vol. 10 (Beirut: Dâr al-Kutub al-'Ilmîyah, 2000), 192.

${ }^{21}$ Hans Wehr, A Dictionary of Written Arabic (New Delhi: Publishing, 1965), 383.

22 Annemarie Schimmel, Dimensi Mistik dalam Islam, terj. Sapardi Djoko Damono, et al. (Jakarta: Pustaka Firdaus, 2003), 139.

23 Pendapat ini berasal dari Ibn Qudâmah seperti dikutip oleh Abdullah, Al-Qur'ân \& Konservasi, 249. 
terhadap sistem pendukung lingkungan bumi. Tuntutan manusia terhadap lingkungan yang semakin besar menimbulkan degradasi tanah, kerusakan akibat polusi, hilangnya keanekaragaman hayati, dan penggundulan hutan yang semakin meluas. Oleh karena itu, para pengamat mengusulkan adanya kerja sama antarberbagai disiplin, terutama antara etis dan teknis, antara tanggung jawab moral dan pengetahuan ilmiah. Penanganan lingkungan bumi di masa depan lebih diharapkan muncul dari individu, keluarga, atau keputusan kelompok dibanding keputusan nasional atau global. ${ }^{24}$

Pola masyarakat yang boros, seperti yang terlihat dalam masyarakat modern telah "memaksa" sistem produksi dalam rangka memenuhi permintaan barang dan jasa yang berakibat pengurasan sumber daya alam yang tidak terkendali dan cenderung membahayakan lingkungan.

Dalam konteks inilah zubd mendapatkan posisi signifikannya untuk membawa manusia agar hidup dalam kesederhanaan, tidak berlebihan. Oleh karena itu, lingkungan hidup akan lebih dapat bertahan dalam masyarakat pedesaan yang hawa nafsu rakusnya relatif dapat dikendalikan.

Al-Qur'ân sendiri (Q.S. al-A'râf ayat 31) sejak awal sudah mengingatkan manusia agar hidup dalam keseimbangan, tidak boros atau berlebihan, menikmati sesuai keperluan.

b. Dhiker dan Fikr

Dhikr dan fiker adalah dua kata yang merefleksikan sikap kontemplatif dan reflektif dengan rasa tunduk kepada Pencipta dan rasa hormat terhadap alam ciptaan Tuhan. Dalam Q.S. Âli Imrân (3): 190-191, Allah menegaskan bahwa dhikr dan fikr adalah dua aktivitas yang simultan yang menjadi syarat bagi predikat orang-orang berakal (ulû al-albâb). Objek dbikr adalah Allah sedang objek fikr adalah semesta alam. Berzikir berarti merenungkan kemahakuasaan Allah yang direfleksikan dalam ciptaan-Nya. Berpikir tentang semesta alam akan membawa kepada kesimpulan kemahabesaran Allah. Oleh karena itu, dhikr dan fikr adalah dua aktivitas yang berujung sama, yaitu mengakui kemahabesaran Allah dan ketinggian nilai ciptaanNya.

Merenung yang reflektif dan mendalam dapat memproduksi kekaguman dan menghasilkan kearifan-kearifan batin, kemudian

24 Audrey R. Chapman, “Sains, Agama, dan Lingkungan”, dalam Bumi yang Terdesak, terj. Dian Basuki dan Gunawan Admiranto (Bandung: Mizan, 2007), 41. 
menghasilkan pikiran, dan mempengaruhi wujud tindakan. Dalam hal ini, termasyhur suatu ungkapan di kalangan sufi "bertafakur sesaat lebih baik dari beribadah setahun". ${ }^{25}$

Dalam konteks konservasi lingkungan, dhikr dan fiker akan memberikan wawasan kepada seseorang tentang relasi Tuhan, alam, dan manusia yang sangat akrab dan menghormatinya sebagai sebuah keniscayaan. Tidak ada yang sia-sia dalam ciptaan Tuhan, semua memiliki mata rantai ekologis yang menopang keharmonisan kehdupan di semesta alam.

\section{c. Hubb}

Hubb atau mahabbah adalah cinta kepada Allah. Dalam tradisi tasawuf, cinta kepada Allah dimaknai dengan makrifat (pengenalan yang mendalam). Al-Ghazâlî mengatakan bahwa, cinta tanpa ma'rifat adalah tidak mungkin, sebab seseorang mencintai sesuatu disebabkan oleh pengenalannya yang mendalam. ${ }^{26}$ Para sufi menyatakan bahwa ma'rifat bukanlah pengenalan yang didasari oleh akal atau intelektual, tetapi pemahaman yang lebih tinggi mengenai rahasia ketuhanan. ${ }^{27}$

Meski kecintaan pada mulanya tertuju kepada Tuhan, tetapi ia memanifestasikan dirinya dalam cinta kepada diri seseorang, kepada sesama, dan kepada alam lingkungan. Dari sinilah ḥubb mendapatkan tempat untuk dapat dibawa dalam kearifan lingkungan. Cinta kepada Tuhan akan berimplikasi pada cinta kepada semua kebaikan, keadilan, kasih sayang, kebenaran, dan akhirnya termasuk mencintai lingkungan.

Tiga konsep tasawuf yang telah diuraikan merupakan nilai-nilai integral yang mampu mendorong pembesaran kapasitas kesadaran spiritual dan intelektual yang lebih permanen untuk selanjutnya menjadi pandangan hidup dalam kerangka konservasi lingkungan. Ekosofi sebagai landasan berpikir yang arif akan menghasilkan konsep-konsep berpikir yang arif pula dan akan mewujudkan tindakan-tindakan nyata yang mengejewantah dalam rancangan dan produk teknologi, ekonomi, norma hukum, dan berbagai kebijakan yang terkait dengan konservasi lingkungan.

\section{Etika Lingkungan}

Dalam konteks konsep dan implementasi, fiqh lingkungan sebagai seperangkat aturan tentang perilaku ekologis yang dirumuskan

25 Abdullah, Al-Qur'ân \& Konservasi, 243.

${ }^{26}$ Annemarie Schimmel, Dimensi Mistik dalam Islam, 166.

${ }^{27}$ Ibid. 
berdasar dalil dengan tujuan menciptakan kemaslahatan dan kelestarian lingkungan, untuk menopang pandangan dunia, tampaknya lebih tepat bila dilihat dalam perspektif etika Islam tentang lingkungan hidup. Etika ${ }^{28}$ tidak hanya berbicara tentang kewajiban-kewajiban sebagai sebuah keharusan berperilaku (formalism, deontologi), seperti yang ada dalam tradisi fiqh, tetapi etika juga mengajarkan bahwa setiap perilaku yang diwajibkan berorientasi kepada tujuan dari perilaku tersebut (teologi). Tujuan akhir dari etika adalah memberikan kesadaran bahwa setiap kebaikan adalah sesuatu yang mesti menjadi tradisi karena universalitas nilai baiknya diterima secara umum. Bahkan, dalam etika religius dan sufistik (filosofis), pertimbanganpertimbangan etika memasuki wilayah kemauan batin dengan kesadaran spiritual dan supranatural. Dengan demikian, fiqh lingkungan yang diproyeksikan sebagai etika lingkungan menurut ajaran Islam akan mampu memberikan kesadaran yang lebih mendalam tentang pentingnya konservasi lingkungan hidup.

Setiap kewajiban yang dengannya akan mendatangkan kemaslahatan, dalam tinjauan etika, adalah sebuah kebaikan. Demikian sebaliknya, setiap larangan yang karenanya akan mendatangkan kemudaratan sama dengan keburukan. Dengan demikian, etika lingkungan bukan saja berisi keharusan-keharusan perilaku ekologis, tetapi perilaku-perilaku itu memang bertujuan untuk kemaslahatan lingkungan. Pertimbangan tujuan dan dampak dari setiap tindakan ekologis menjadi sangat penting dalam etika lingkungan.

Etika lingkungan dalam Islam sebagai etika religius ${ }^{29}$ menggambarkan perilaku-perilaku yang seharusnya dilakukan atau ditinggalkan dalam hubungan manusia dengan lingkungannya. Etika ini secara filosofis bersumber dari spirit moral yang digali dari ayat-

${ }^{28}$ Etika berasal dari bahasa Yunani Kuno ethos (jamak ta etha) yang secara etimologi berarti adat istiadat atau kebiasaan. Dalam makna istilah, kata etika dapat memberikan arti "sistem nilai", "kumpulan asas atau nilai moral" (kode etik), dan "ilmu etika" sebagai refleksi penelitian sistematis dan metodis atau filsafat moral. Dalam penggunaan praktis, istilah etika sama dengan moral. Lihat K. Bertens, Etika (Jakarta: PT Gramedia Pustaka Utama, 2007), 6; Miftahul Huda, Al-Qur'ân dalam Perspektif Etika dan Hukum (Yogyakarta: Teras, 2009), 1; Peter A. Angeles, Dictionary of Philosophy (New York: Barnes \& Noble Book, 1931), 82; Keraf, Etika, 14.

29 Ada empat tipe etika Islam: moralitas skriptural, teologis, filosofis, dan religius. Etika religius adalah sistem nilai praktis yang bersumber dari spirit moralitas Islam, baik al-Qur'ân, maupun al-Ḥadîth. Lihat Majid Fakhry, Etika dalam Islam, terj. Zakiyuddin Baidhawy (Yogyakarta: Pustaka Pelajar, 1996), xxi-xxiii; Suparman Syukur, Etika Religius (Yogyakarta: Pustaka Pelajar, 2004), 196. 
ayat al-Qur'ân dan al-Ḥadîth. Oleh karena itu, etika lingkungan akan melahirkan sistem nilai yang dinamis yang salah satunya adalah berwujud dalam fiqh yang sesuai dengan situasi dan kondisi di mana nilai itu hendak diterapkan. Secara epistemologis, sumber etika lingkungan diproses melalui metode perumusan fiqh yang dibahas dalam ușul al-fiqh.

Dalam metodologi fiqh Islam, ketentuan etika (baik dan buruk) dapat dinalar tidak hanya semata-mata melalui teks itu sendiri, tetapi dapat pula melalui pesan moral Ilahi yang dapat ditangkap dari teksteks wahyu itu. Dengan universalitasnya, wahyu - terutama untuk teks-teks yang mendasari fiqh lingkungan-memiliki inti pesan yang dapat digali melalui ijtihâd. Penjabaran teknis dari pesan-pesan moral ilahi itu diwujudkan dengan pertimbangan sosiologis dan kontekstual. Dalam konteks etika lingkungan, pesan moral ilahi itu dapat ditemukan dalam setiap dalil yang berbicara tentang hubungan manusia dengan alam.

Prinsip-prinsip dasar etika lingkungan yang terkandung dalam alQur'ân dan al-Hadîth dapat dirinci sebagai berikut.

1. Prinsip kepemilikan mutlak. Prinsip ini menegaskan bahwa semesta alam adalah mutlak milik Allah sebagai Pencipta, Pengatur, dan Pengarah. Tiga kata ini merupakan makna yang terkandung dalam kata rabb yang dalam al-Qur'ân senantiasa diikuti (disandarkan) dengan alam dan bagian-bagiannya. ${ }^{30}$ Konsekuensi dari prinsip pertama ini adalah bahwa setiap perilaku menjaga dan memperbaiki (konservasi) terhadap alam dengan segala isinya sama dengan memenuhi kehendak Allah sebagai pemilik mutlak dari alam tersebut. Demikian juga sebaliknya.

2. Prinsip pengelolaan dengan amanah. Prinsip ini menegaskan bahwa meski alam semesta diciptakan dan ditundukkan bagi manusia, ${ }^{31}$ tetapi manusia harus bertanggung jawab dalam mengelolanya, tidak boleh melampaui batas dan tidak boleh mengikuti keinginan tidak terbatas. Dengan prinsip ini, eksploitasi alam tidak dibenarkan apabila akan mandatangkan kemudaratan. Meskipun manusia diberi fungsi sebagai khalifah, tetapi kekhalifahan itu harus dimanfaatkan sebesar-besarnya untuk kemanfaatan kehidupan, termasuk konservasi alam. Manusia berkewajiban menghantarkan alam sesuai untuk apa ia diciptakan.

30 al-Qur'ân, 1: 2; al-Qur'ân, 2: 284.

31 al-Qur'ân, 14: 32-33; al-Qur'ân, 6:141-142; al-Qur'ân, 57: 7. 
Dengan demikian, dapat dipahami larangan Rasulullah untuk menjual buah sebelum layak dipanen, ${ }^{32}$ karena di samping dapat menimbulkan konsekuensi ketidaktepatan dalam hitungan kuantitas buah tersebut saat dipanen (aspek transaksi), juga akan mengakibatkan pelanggaran hak (ekologis) bagi buah tersebut untuk dapat berkembang sampai layak dipanen. Prinsip ini menegaskan pula bahwa Islam tidak mengajarkan antroposentrisme mutlak, tetapi antroposentrisme yang bertanggung jawab.

3. Prinsip penggunaan yang hemat. Prinsip ini bersumber dari alQur'ân yang melarang sikap boros (mubadhdhir). ${ }^{33}$ Di samping itu, dalam hadîth riwayat Abû Dâwud, Rasulullah melarang berbuat isrâf atau melampaui batas dalam menggunakan air untuk bersuci. Rasulullah dalam riwayat tersebut mandi dengan air satu $s a^{\prime}(3,363$ liter) dan berwudu dengan air satu mud (1,032 liter). ${ }^{34}$ Prinsip ini memberikan arah pemanfaatan sumber daya alam yang berimbang untuk keberlanjutan.

4. Prinsip tanggung jawab risiko. Prinsip ini mengajarkan bahwa segala kerusakan alam disebabkan oleh kecerobohan manusia. ${ }^{35}$ Dengan kemampuan sains dan teknologi, manusia dapat menguasai alam (taskhîr), tetapi risiko akibat eksploitasi yang tidak bertanggung jawab telah ditegaskan diingatkan oleh al-Qur'ân. Dalam konteks etika lingkungan, pertimbangan dampak (al-nažr ilâ al-ma'ấ) dalam setiap program pengelolaan alam harus dipertimbangkan secermat mungkin.

Empat prinsip ini melahirkan etika religius lingkungan yang mengajarkan keseimbangan relasi antara Tuhan, manusia, dan alam. Etika ini melampaui asas keseimbangan dan kesatuan ekosistem yang hingga saat ini masih banyak digunakan oleh ilmuwan dan praktisi lingkungan dalam merumuskan kebijakan pengelolaan lingkungan. Etika lingkungan dengan asas keseimbangan dan kesatuan tersebut

\footnotetext{
${ }^{32}$ Hadîth tersebut diriwayatkan oleh Bukhârî:

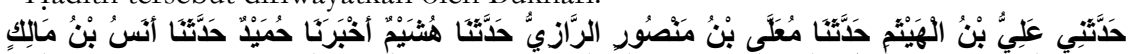

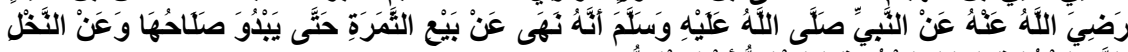

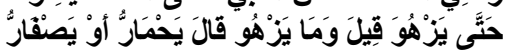

33al-Qur'ân, 17: 26-27.

${ }^{34}$ Hadith tersebut berbunyi:

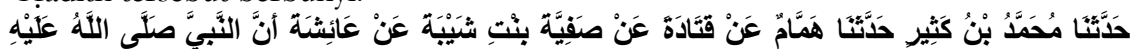

${ }^{35}$ Lihat antara lain al-Qur'ân, 30: 41.

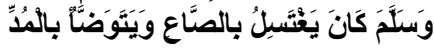


masih terbatas pada dimensi fisik dan duniawiah, belum dikaitkan dengan dimensi supranatural dan spiritual, khususnya dimensi Tuhan sebagai pemilik mutlak semesta alam. Dari sinilah, kemudian dapat dipahami bahwa etika religius yang bersumber dari al-Qur'ân dan alHadîth lebih holistik dalam menilai hubungan antara manusia dan lingkungannya.

Etika lingkungan hidup mengajarkan tentang bagaimana manusia harus bertindak, atau bagaimana perilaku manusia yang seharusnya terhadap lingkungan hidup. Etika lingkungan hidup adalah disiplin ilmu yang berbicara mengenai norma dan kaidah moral yang mengatur perilaku manusia dalam hubungannya dengan alam serta nilai dan prinsip moral yang menjiwai perilaku manusia dalam berhubungan dengan alam tersebut. Dengan demikian, etika lingkungan hidup lebih dipahami sebagai sebuah kritik atas etika yang selama ini dianut oleh manusia yang dibatasi hanya pada komunitas sosial manusia. Etika lingkungan hidup menuntut agar etika dan moralitas tersebut diberlakukan juga bagi komunitas biotis atau komunitas ekologis. Dengan kata lain, kendati makhluk selain manusia bukan sebagai pelaku moral, sewajarnya mendapat perhatian moral karena mereka dipandang sebagai subjek moral pula. Dengan demikian, etika lingkungan dikonsepsikan sebagai refleksi kritis tentang apa yang harus dilakukan manusia dalam menghadapi pilihanpilihan moral yang terkait dengan isu lingkungan hidup, termasuk apa yang harus diputuskan oleh pemerintah dalam kebijakan ekonomi dan politik yang berdampak pada lingkungan hidup.

Berdasarkan uraian tersebut, konsep etika bukan saja berbicara tentang baik dan buruk dan untuk tujuan apa suatu perilaku itu diperbuat, tetapi ranah etika memasuki wilayah batin. Hal itu dapat dilihat dalam konsep Immanuel Kant yang menekankan aspek batin dalam menentukan nilai baik dan buruk. Menurutnya, yang dapat dianggap "baik" dalam arti yang sesungguhnya hanyalah niat (motif) yang baik, sedangkan yang lain hanya dapat disebut baik secara terbatas atau dengan syarat tertentu. ${ }^{36}$ Dengan demikian, suatu perbuatan dikatakan baik secara moral jika bertolak dari motif atau niat yang baik pula, yaitu suatu kesadaran bahwa melakukan perbuatan itu merupakan sebuah panggilan kewajiban moral. Mengomentari pendapat Kant, Franz Magnis-Suseno mengatakan bahwa moralitas adalah pelaksanaan kewajiban yang didorong oleh rasa hormat kepada

${ }^{36}$ K. Berten, Etika, 256. 
hukum, peraturan, atau undang-undang. Adapun hukum itu sendiri tertulis dalam hati manusia. Sebuah hukum atau aturan yang berasal dari luar diri seseorang hanya akan mengikat bila aturan itu diyakini kebenarannya dalam hati. Jadi, moralitas adalah tekad untuk mengikuti apa yang ada dalam hati yang disadari sebagai kewajiban mutlak. ${ }^{37}$ Dalam Islam, setiap ketentuan (anjuran dan larangan) senantiasa dikaitkan dengan semangat tauhid. Ayat-ayat al-Qur'ân dan al-Ḥadîth yang berisi suruhan dan larangan senantiasa berisi semangat spiritual dari hati yang dalam. ${ }^{38}$ Hampir dalam setiap ayat yang berisi suruhan dan larangan, Allah menyapa dengan kalimat "Hai orang-orang yang beriman". Kata "orang-orang yang beriman" memberikan kesan sebagai orang-orang yang memiliki kesadaran batin yang tinggi.

Kutipan-kutipan tersebut menggambarkan aspek batin yang mesti harus ada dalam setiap pelaksana aturan hukum. Hukum yang sematamata sebuah aturan sebagai hasil konsiderasi akademik akan kering dan mudah dimanipulasi dalam pelaksanannya. Demikian juga dengan fiqh lingkungan, di samping sebagai aturan hukum, mesti berisi nuansa batin sebagai konsekuensi moral yang mendorong pelakunya untuk berniat baik dalam mewujudkan aturan hukum tersebut dalam praktik kehidupan nyata.

Beberapa teoretikus fiqh lingkungan, seperti Othman Abd arRahman Llewellyn berpendapat bahwa pencitraan fiqh Islam sebagai sebuah hukum sama dengan term "hukum" dalam peradaban Barat mungkin menyesatkan. Parahnya lagi, pemikiran tentang hukum agama menimbulkan gambaran tentang pembatasan-pembatasan tidak beralasan dan hukuman-hukuman keras. ${ }^{39}$ Hukum dalam peradaban mereka jauh dari nilai-nilai etika agama. Berbeda dengan hukum dalam Islam, di samping sebagai aturan, hukum memiliki dimensi moral yang mengajarkan baik dan buruk dengan segala dampaknya

${ }^{37}$ Franz Magnis-Suseno, Filsafat sebagai Ilmu Kritis (Yogyakarta: Kanisius, 1992), 104.

${ }^{38}$ Ketika menanggapi para sahabat yang ingin ikut hijrah ke Yathrib, Rasulullah menekankan aspek batin berupa ketulusan niat dalam ikut berhijrah, sebuah nasihat yang menyentuh aspek esoteris. Hadîth yang diriwayatkan oleh Bukhari itu berbunyi:

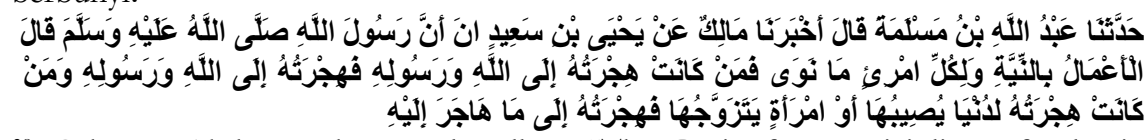

39 Othman Abd ar-Rahman Llewellyn, "The Basic for a Dicipline of Islamic Environmental Law", dalam Richard C. Foltz, et al. (ed.) Islam and Ecology a Bestowed Trust (USA: Harvard University Press, 2003), 186-187. 
dan dilaksanakan atas dasar kesadaran spiritual yang tinggi. Dalam konteks peradaban Islam, dapat dipahami kalau hukum (fiqh) dilahirkan dari sharî'ah—yang secara harfiah bermakna "jalan menuju air" atau "sumber kehidupan". Fiqh adalah hasil pemahaman tentang bagaimana melakukan kehendak Yang Maha Pengasih dan Maha Penyayang, Tuhan segala makhluk, dan bagaimana menjalani hidup secara individu atau kolektif dengan cara yang paling beretika dan bermoral.

Di samping itu, sesungguhnya ilmu tentang etika dan hukum pada dasarnya satu dan sama, yakni berbicara tentang perilaku manusia untuk mencari keabsahan dan nilai kebaikan. Konsep kesamaan inilah yang berlaku dan dipraktikkan pada zaman Rasulullah dan para sahabatnya. Oleh karena itu, dapat dipahami alasan paling umum orang mencari mufti atau ahli hukum Islam adalah untuk bertanya tentang tindakan yang paling bermoral dan beretika dalam satu situasi tertentu, tindakan yang paling menyenangkan Tuhan segala makhluk dan tindakan yang paling pasti menuju alam keabadian. ${ }^{40}$

Apabila fiqh lingkungan dipahami sebagai etika yang berarti bukan hanya sebatas aturan baik buruk, untuk apa perbuatan itu diwujudkan, dan niat apa yang terkandung di dalam pribadi seseorang yang melaksanakannya, maka dimensi sufistik kiranya dapat pula dimasukkan dalam etika ini. Meskipun terdapat sedikit kesulitan dalam menyusun konsep sistematik tentang etika tasawuf, ${ }^{41}$ karena menurut para sufi, etika bukan sesuatu yang diteoretisir, tetapi sebuah pengalaman religius yang lebih bernuansa emosional, tetapi masih dimungkinkan hal itu diketahui melalui konsep-konsep sufistik semisal fiqh model al-Ghazâlî.

Dalam perspektif al-Ghazâlî, terutama dalam bahasan-bahasan fiqh yang terdapat dalam Ihyấ, fiqh dan dimensi esoterisnya sebagai kesatuan fundamental dalam Islam. Ihyâ' 'Ulûm al-Dîn secara etimologi bermakna "menghidupkan ilmu-ilmu agama". Hal ini memberikan

\footnotetext{
40 Ibid.

${ }^{41}$ Meski etika tasawuf belum benar-benar refresentatif sebagai sebuah teori karena berkait dengan pengalaman subjektif emosional, tetapi masih terdapat dua jalan untuk mendekati konsep etika tasawuf itu. Pertama, melalui ide-ide fundamental yang mendasari sejumlah pemikiran utama tasawuf. Kedua, dari sisi kajian fenomenologis. Hal itu dapat dilihat dalam konsep-konsep wạ̣dat al-wnjûd Ibn 'Arabî, insân kâmil alJîlî, dan ishrâq Suhrawardî al-Maqtûl beserta praktik kehidupan mereka dengan shatahât-shatahât-nya.
} 
kesan "kematian" ilmu-ilmu agama itu, ${ }^{42}$ atau ilmu yang tidak berdaya guna memberikan perubahan. Untuk tujuan "menghidupkan" itu, alGhazâlî membungkus ilmu fiqh dalam wadah tasawuf. Tasawuf yang secara harfiah bermakna kebersihan, disandingkan dengan bahasan hukum fiqh, sehingga hukum fiqh dilaksanakan dalam kesadaran untuk membersihkan diri di samping sebagai pelaksanaan kewajiban. ${ }^{43}$ Kalau diikuti cara berpikir al-Ghazâlî ini, maka aturan-aturan hukum yang berkaitan dengan lingkungan (UU atau fiqh lingkungan) tetap akan mati tanpa bungkusan etika tasawuf. Dari inti pesan yang dapat digali dalam model fiqh al-Ghazâlî ini, fiqh lingkungan sebagai etika lingkungan sesungguhnya sarat dengan nilai-nilai ketuhanan yang mengharuskan pelaksanannya diwujudkan secara sadar dan ikhlas sehingga menjadi sebuah moral yang terpatri dalam kehidupan.

Etika lingkungan sebagai bagian dari ajaran Islam yang mengajarkan moral semakin urgen dalam kehidupan masyarakat modern karena sikapnya yang cenderung konsumtif dan antroposentris. Relasi manusia dan lingkungan yang dipahami sebagai etika akan mampu memberikan penyadaran bahwa hubungan antara keduanya bukan semata-mata ditakar dengan rumusan hukum, tetapi menyangkut aspek moral dengan segala konsekuensinya.

Fiqh sebagai etika ini adalah sebuah cita-cita yang sebenarnya sudah pernah terwujud ketika fiqh (hukum) tidak dilihat terpisah secara dikotomis dari etika (moral). Pada awalnya, ketika zaman Nabi Muhammad masih hidup, tidak ada dikotomi antara hukum dan moral, baik dalam teori maupun praktik. Setiap hukum dilaksanakan penuh dengan tanggung jawab sebagai manusia bermoral. Nabi sendiri membuat pernyataan tegas bahwa "aku diutus untuk menyempurnakan akhlaq". ${ }^{44}$ Buah dari perjuangan Rasul itu tampak

42 Karena kitab Ibyâ' membahas fiqh dalam dimensi etika sufistik, besar kemungkinan ilmu yang dianggapnya mati suri itu adalah fiqh.

${ }^{43}$ Salah satu sampel bahasan fiqh berdimensi etika sufistik dalam Ibyâ' adalah ulasan al-Ghazâlî tentang tahârah yang dibaginya menjadi empat bagian: bersuci dari najis dan hadath, bersih anggota tubuh (jawârih) dari perbuatan dosa, bersih hati dari akhlaq tercela, dan yang paling tinggi adalah bersih hati dan pikiran dari segala bentuk kesibukan selain mengingat Allah. Lihat Abû Hâmid al-Ghazâlî, Ibyyâ Ulùm ad-Din bab tahârah.

44 al-Bayhaqî, Al-Sunan al-Kubrâ, Vol. 10, 192. Kalau dilihat secara normatif, penegakan etika jauh lebih penting dari sekadar pelaksanaan hukum. Dalam hadîth riwayat Bukhari dan Muslim ditegaskan bahwa orang yang terbaik itu adalah orang yang paling baik akhlaqnya, dan apabila sudah tidak punya malu (tidak punya rasa 
terlihat dari kesadaran umatnya yang cukup tinggi untuk hidup dalam naungan ajaran Islam. Dalam suatu riwayat diceritakan bahwa seorang pelaku pelanggaran hukum, tanpa disidik, datang mengaku bersalah di hadapan Rasulullah saw dan meminta ditegakkan hukum. ${ }^{45}$

Akan tetapi, dalam perkembangan pemikiran umat Islam selanjutnya ternyata cenderung menguatkan citra bahwa hukum hanya mengurusi hal-hal yang bersifat lahiriah saja yang kemudian melahirkan disiplin kajian fiqh. Aspek batini dibahas tersendiri dalam disiplin lain, yaitu tasawuf. ${ }^{46}$ Keterpisahan dua ilmu ini dalam ranah realitas sosial melahirkan praktik-praktik fiqh—dan juga semua peraturan perundangan-undangan dalam sebuah negara-yang bersifat ambigu, melahirkan pribadi-pribadi dan lembaga-lembaga yang bersikap mendua (split personality). Kemandulan berbagai lembaga penegak hukum dalam mewujudkan rasa keadilan masyarakat melalui proses pengadilan lebih disebabkan oleh penegak hukum yang ambigu, bukan oleh materi hukumnya.

Perkembangan kedua disiplin ilmu ini semakin meneguhkan konsep pemisahan sehingga antara keduanya semakin menjauh, baik dalam teori maupun praktik. Masing-masing pihak memiliki epistemologi sendiri yang mengakibatkan semacam "kompetisi" yang tidak sehat dan berakibat korban pembunuhan intelektual, bahkan korban jiwa. Cerita Abdul Hamid Abulung ${ }^{47}$ era Muhammad Arsyad al-Banjari, Syekh Siti Jenar ${ }^{48}$, dan al-Hallâj ${ }^{49}$ adalah sebagian dari contoh pertentangan hebat antara kaum sufi dan fuqaha'.

empati dalam interaksi kehidupan), silakan berbuat sekehendaknya (sebuah ancaman psikologis untuk tidak dihargai) ان اخياركم احاسنكم اخلاقا إذا لم تستحى فاصنع ما شئت

45 Dalam hadîth riwayat Bukhari dan Muslim, seorang yang bernama Mâ’iz mendatangi Rasulullah minta dihukum karena dia telah berbuat zina.

${ }^{46}$ Huda, Al-Qur'ân dalam Perspektif Etika, 159.

47 Tokoh Sufi ini hidup tahun 1148-1203 semasa dengan Shaykh Arsyad al-Banjari (1122-1227). Ajaran tasawufnya yang dianggap bertentangan dengan paradigma figh adalah waḥdat al-wujûd (kesatuan wujud).

${ }^{48}$ Tokoh Shaykh Siti Jenar yang hidup pada awal perkembangan Islam, sekitar abad ke-16 M., dalam beberapa analisis masih menyisakan banyak pertanyaan, termasuk ada tidaknya sosok yang bernama Syekh Siti Jenar tersebut. Akan tetapi, yang masyhur di kalangan masyarakat Jawa, sosok ini adalah seorang sufi agung sekaliber Wali Songo. Tokoh ini, dalam beberapa analisis, mengajarkan wậdat al-wujûd seperti yang dibawa oleh Ibn 'Arabî. Oleh karena ajaran ini menafikan kewajiban syariat, maka Pangeran Raden Patah (sekitar akhir abad ke XV M), atas hasil kesepakatan wali songo, memberikan hukuman mati. Analisis lain mengatakan bahwa dia enggan memenuhi undangan istana dan memilih sendiri jalan kematian. Lihat John Rinaldi, 
Dalam perspektif sedikit berbeda, etika religius juga ditawarkan oleh Sofyan Anwar Mufid yang menawarkan paradigma baru tentang cita-cita membangun lingkungan hidup dalam perspektif ajaran Islam. Dalam bukunya Islam dan Ekologi Manusia, ia mengegaskan bahwa tidaklah cukup membahas ekologi hanya dalam perspektif hubungan antara manusia dan alam, kecuali harus melibatkan komponen mental spiritual yang ia sebut sebagai sesuatu yang universal, karena pada jati diri setiap manusia sebenarnya terdapat potensi itu. Potensi spiritual dapat berbentuk agama, kepercayaan, ritus-ritus sakral, dan pemujaan. ${ }^{50}$

Dengan tesisnya itu, Sofyan ingin menegaskan bahwa kesalehan ekologi tidak akan selesai dengan aturan-aturan yang bersumber dari norma adat dan norma hukum positif saja, tetapi harus melibatkan norma Tuhan yang berwujud dalam aturan-aturan agama. Kesejahteraan manusia sebagai khalifah diakuinya sebagai tujuan tertinggi penciptaan. Manusia secara ekologis diposisikan di tengahtengah makrokosmos sebagai salah satu komponen mikrokosmos jenis biotik teristemewa dibandingkan dengan hampir dua juta jenis makhluk hidup lainnya. Di sisi lain, secara spiritual, manusia dituntut harus mempunyai komitmen dan integritas kepada Sang Pencipta. Pertanggungjawaban itu kemudian direfleksikan melalui interaksiinteraksi dalam ekosistem khusus yang dibangun di atas alam fisik, nonfisik, dan metafisik. ${ }^{51}$

Konsep yang ditawarkan Sofyan tersebut adalah bagian dari memperjuangkan aturan-aturan pengelolaan lingkungan hidup (salah satunya adalah fiqh) dalam bungkusan semangat etika moral yang bersumber dari ajaran transenden, sehingga aturan-aturan itu

Syekh Siti Jenar Dunia sebagai Alam Kubur (Yogyakarta: Pustaka Pelajar, 2008), 67-70 dan 128 - 129.

49 Al-Hallâj lahir tahun 224 di Tur, Persia. Ia hidup pada masa pemerintahan Bani 'Abbâs. Karena konflik dengan penguasa yang ketika itu dipimpin oleh Khalifah alMu'tasim, al- Hallâj dijatuhi hukuman mati tanggal 18 Dhû al-Qa'dah 309. Terdapat beberapa versi tentang akar konflik antara al-Ḥallâj dengan penguasa. Sebagian pendapat mengatakan karena ajaran ḅulull-nya yang dianggap berseberangan dengan fiqh, sebagian yang lain mengatakan karena perbedaan ideologi politik al-Hallaj dituduh punya hubungan dengan gerakan Qarâmitah, sekte Shî‘ah yang mempunyai paham komunis. Lihat Harun Nasution, Filsafat dan Mistisisme dalam Islam (Jakarta: Bulan Bintang, 1973), 87.

50 Sofyan Anwar Mufid, Islam dan Ekologi Manusia (Bandung: Nuansa, 2010), 29.

${ }^{51}$ Ibid., 30. 
diwujudkan melalui hati yang dalam dengan niat pengabdian kepada Tuhan.

\section{Penutup}

Refleksi interaktif antara fiqh, kalam/tauhid, dan tasawuf/etika dalam memahami figh lingkungan akan memberi kesadaran bahwa fiqh adalah seperangkat hukum yang juga bernuansa spiritual. Fiqh bukan semata lima varian hukum taklifi sebagai interpretasi norma secara deduktif atau kristalisasi maqâsid al-sharîah secara induktif, tetapi fiqh itu suatu titah Tuhan yang harus dimengerti dan diterima secara batin. Fiqh bukan sekadar perintah dan larangan, tetapi suatu perintah kemaslahatan dan larangan kemafsadatan yang diterima sesuai fitrah kemanusiaan. Hal ini mendorong untuk dirumuskannya pemahaman fiqh yang secara ontologis tidak menyendiri dan berhenti pada aspek yuridis formal, tetapi pada aspek filosofis dan sosiologis.

\section{Daftar Rujukan}

Abdullah, Mudhofir. Al-Qur'an \& Konservasi Lingkungan. Jakarta: Dian Rakyat, 2010.

Angeles, Peter A. Dictionary of Philosophy. New York: Barnes \& Noble Book, 1931.

Banjari (al), Muhammad Nafîs. al-Durr al-Nafìs. Singapura: AlHaramain, t.th.

Bayhaqî (al), Abû Bakr Aḥmad b. al-Ḥusayn b. 'Alî b. Mûsâ. Al-Sunan al-Kubrâ, Vol. 10. Beirut: Dâr al-Kutub al-'Ilmîyah, 2000.

Bertens, K. Etika. Jakarta: PT Gramedia Pustaka Utama, 2007.

Chapman, Audrey R. "Sains, Agama, dan Lingkungan", dalam Bumi yang Terdesak, terj. Dian Basuki dan Gunawan Admiranto. Bandung: Mizan, 2007.

Fakhry, Majid. Etika dalam Islam, terj. Zakiyuddin Baidhawy. Yogyakarta: Pustaka Pelajar, 1996.

Ghazâlî (al), Abû Ḥâmid. Ihyâ Ulûm ad-Dîn bab tahârah. t.t.: t.p., t.h.

Huda, Miftahul. Al-Qur'ân dalam Perspektif Etika dan Hukum. Yogyakarta: Teras, 2009.

Keraf, Sony. Etika Lingkungan. Jakarta: Kompas, 2002.

Llewellyn, Othman Abd ar-Rahman. "The Basic for a Dicipline of Islamic Environmental Law", dalam Richard C. Foltz, et al. (ed.) Islam and Ecology a Bestowed Trust. USA: Harvard University Press, 2003.

Magnis-Suseno, Franz. Filsafat sebagai Ilmu Kritis. Yogyakarta: Kanisius, 1992. 
Mufid, Sofyan Anwar. Islam dan Ekologi Manusia. Bandung: Nuansa, 2010.

Nasution, Harun. Filsafat dan Mistisisme dalam Islam. Jakarta: Bulan Bintang, 1973.

Nur, Kautsar Azhari. "Wahdatul Wujud Ibn Arabi dan Panteisme". Disertasi--IAIN Syarif Hidayatullah, Jakarta, 1993.

Rahman, Fazlur. Tema-tema Pokok al-Qur'an, terj. Anas Mahyuddin. Bandung: Pustaka, 1993.

Rinaldi, John. Syekh Siti Jenar Dunia sebagai Alam Kubur. Yogyakarta: Pustaka Pelajar, 2008.

Schimmel, Annemarie. Dimensi Mistik dalam Islam, terj. Sapardi Djoko Damono, et al. Jakarta: Pustaka Firdaus, 2003.

Susilo, Rakhmad K. Dwi. Sosiologi Lingkungan. Jakarta: Rajawali, 2008.

Syukur, Suparman. Etika Religius. Yogyakarta: Pustaka Pelajar, 2004.

Wehr, Hans. A Dictionary of Written Arabic. New Delhi: Publishing, 1965.

Zakariyâ, Ibn Fâriz b. Mưjam Maqâyis al-Lughah. Mesir: Muștafâ alBâb al-Hạabî, 1972. 